\title{
Ultra-sensitive Alpine lakes and climate change
}

\author{
Roy THOMPSON*, Christian KAMENIK ${ }^{1,2)}$ and Roland SCHMIDT ${ }^{1)}$ \\ School of GeoSciences, The University of Edinburgh, Edinburgh EH9 3JW, Scotland \\ ${ }^{11}$ Institute of Limnology, Austrian Academy of Sciences, Mondseestraße 9, A-5310 Mondsee, Austria \\ ${ }^{2)}$ Present address: Paleoecology, Institute of Plant Sciences, University of Bern, Altenbergrain 21, CH-3013 Bern, Switzerland \\ *e-mail corresponding author: roy@ed.ac.uk
}

\begin{abstract}
Global warming is one of the major issues with which mankind is being confronted, having vital ecological and economic consequences. Ice-cover, snow-cover and water temperatures in alpine catchments are controlled by air temperatures, and so are very susceptible to shifts in climate. Local factors such as wind exposure, shading, and snow patches that persist during cold summers can, however, modify the sensitivities of the relationships to air temperature. Thermistors exposed in 45 mountain lakes of the central Austrian Alps (Niedere Tauern) measured water temperatures during 1998 - 2003 at two or four hourly intervals. Degree-day and exponential smoothing models tuned with this data suggest we can anticipate extremely large temperature rises in some of the Niedere Tauern lakes in the coming century. Lakes at around 1500 to $2000 \mathrm{~m}$ altitude are found to be ultra-sensitive as they lie in the elevation range where changes in both ice-cover and snow-cover duration will be particularly pronounced. In the more extreme cases, our impact models predict a summer-epilimnion water-temperature rise of over 10 degrees. One example of a lake most at risk to future climate change is Moaralmsee. This lake is located at $1825 \mathrm{~m}$ a.s.l. on the northern slopes of the Niedere Tauern; its water temperature is likely to rise by 12 degrees. The projected water discharge, ice-cover duration and water temperature changes for the Tauern catchments in the coming century far exceed the variations experienced at any stage during the last ten thousand years.
\end{abstract}

Key words: Alpine, lake, climate change, snowmelt, epilimnion temperature

\section{INTRODUCTION}

The importance of feedbacks and non-linearities in the climate system was first elaborated by Croll (1875) in his farsighted discourse on changes in the Earth's climate and the cause of glaciations. He argued that past changes in the environment came about as a consequence of complex interactions between the component parts of the earth system especially the ice-sheets, atmosphere and ocean currents. Croll noted that:

"...it is quite a common thing in physics for the effect to react on the cause <although $>$ it is usually ... the case that the reaction of the effect tends to weaken the cause. But, strange to say, in regard to the physical causes concerned $<$ with $>$ the condition of climate, cause and effect ... mutually aid one another".

Today the global climate is changing rapidly, possibly at a faster rate than at any time in the last ten thousand years with surface temperatures having increased by $0.6^{\circ} \mathrm{C}$ in the last century (Jones et al. 1999; Jones \& Moberg 2003). These increases have, in part, been caused by changes to the composition of Earth's atmosphere brought about by the burning of fossil fuels (Houghton et al. 2001). Natural archives of ice, treerings and lake sediment, can hold detailed records of past climate variations (e.g. Battarbee et al. 2004). Such archives indicate how the climate during the Holocene (the last 10,000 years - the time since the transition from the last glacial) has been relatively stable (Stenni et al. 2001), with subdued global climatic fluctuations, compared to the rapid changes of glacial times (Taylor et al. 1993). Indeed the Holocene appears to have been by far the longest warm, stable period over the last 400 ka a situation which doubtlessly favoured the development of human civilisation (Petit et al. 1999). Looking towards the future it seems likely that human activities will continue to change the composition of Earth's atmosphere by adding more and more greenhouse gases. It seems inevitable that these gases will further impact on the global climate (Houghton et al. 1996; Houghton et al. 2001) and cause further climate change. Temperature rises of 1.4 to $5.8{ }^{\circ} \mathrm{C}$, by 2100 , are anticipated in many GCM-based climate change scenarios (Houghton et al. 2001). Local climate change can be expected to be even more variable than the climate on a global scale as local variations in one region can be compensated for by opposite variations elsewhere. A recent study (Schar et al. 2004) suggests that in central Europe a locally enhanced warming will be engendered by a coupling between soil moisture and atmospheric dynamics, causing significant additional increases to summer air temperature.

A particularly powerful means of reconstructing past climatic conditions is through the use of "space-time" transfer functions, a technique first pioneered by Imbrie \& Kipp (1971). In lake sediment based studies a regional training set is constructed by monitoring the present day properties of a suite of lakes spanning the 


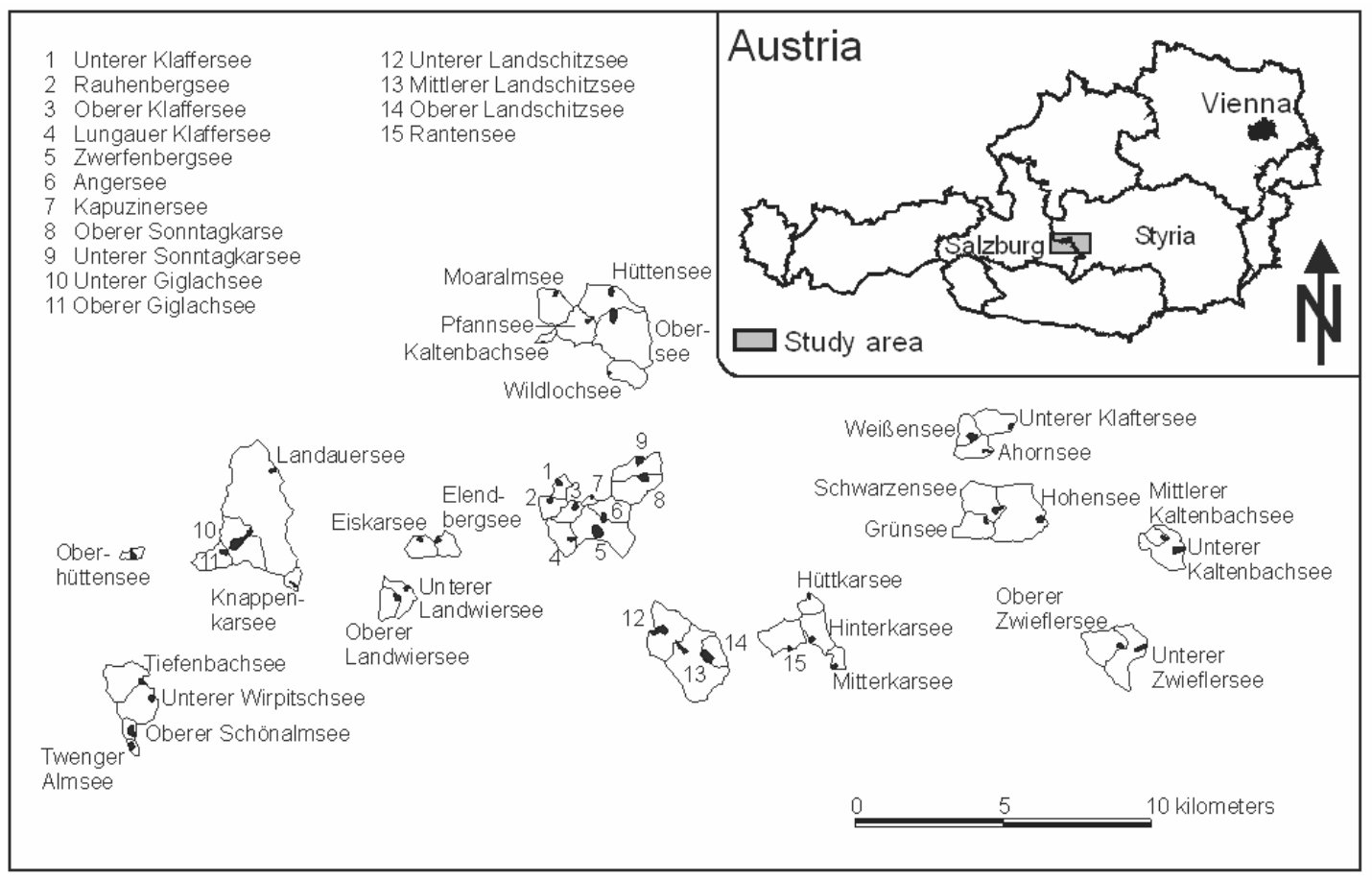

Fig. 1. Niedere Tauern. Location of training set lakes used in thermistor study. Inset shows general location of the Niedere Tauern.

climatic range of interest (e.g., a staircase of lakes on an altitudinal gradient). A mathematical transfer function is derived that best relates the contemporary sediment properties (e.g., taxon assemblages) to the present day climatic conditions. The normal use of such transfer functions is to apply them to fossil assemblages in order to reconstruct the past climate (Birks 1998). Here instead we use the relationships found in a 45 lake training set from the Niedere Tauern area of the central Austrian Alps to assess the sensitivity of the lakes to climate and hence to make predictions of the likely impact of any future climate change on the lakes. Just as Croll (1875) drew attention to the importance of snow and ice feedbacks and non-linearities in the global climate system, we highlight the significance of snowpack effects in the catchments of the Niedere Tauern lakes and the pronounced changes that can ensue if their climatic thresholds are passed.

The future climate will likely produce longer icefree periods and higher surface-water temperatures on alpine lakes. Ice-cover is the most dramatic physical event which influences lake ecology (Gabathuler 1999), as ice covered by snow virtually decouples lake and atmospheric processes (Gray \& Male 1981). Fee et al. (1992) have found that as the ice-free period, on small lakes, increases so does primary production; while Regier et al. (1990) suggest that an increase in water temperature of $10{ }^{\circ} \mathrm{C}$ may lead to a four-fold increase in primary production. Changes in the species composition of algae, the timing of the spring phytoplankton bloom and in the seasonal pattern of productivity are additional likely consequences of climate change (Gerten \&
Adrian 2002). Primary production however is also controlled by the availability of nutrients. When nutrients are high, overall production is found to vary with temperature and the duration of the ice free period (Fee et al. 1992; Shuter \& Ing 1997). However, when nutrient availability is low, overall production is much less sensitive to changes in temperature (Shuter \& Ing 1997). Feedbacks between temperature and primary production are feasible because phytoplankton cells and colonies can both scatter and absorb light. Backscattering, which reduces temperatures, is low for living cells but much greater for dead mineral particles. Satellite remote sensing in the oceans, in the absence of vertical mixing effects, demonstrate such associations by the occurrence of high reflectances and reduced water temperatures in phytoplankton rich areas (Stramski \& Kiefer 1991; Stramski et al. 1999)

\section{METHODS}

\subsection{Study area - Niedere Tauern}

The Niedere (Schladminger) Tauern Alps (NT) form a compact $\left(4457 \mathrm{~km}^{2}\right)$ but imposing massif of crystalline and limestone bedrock, centred at $47^{\circ} 19^{\prime} \mathrm{N}$, $14^{\circ} 3^{\prime} \mathrm{E}$, astride the main alpine ridge (Fig. 1). The highest peaks rise to $2862 \mathrm{~m}$, just below the altitude (around $3000 \mathrm{~m}$ ) at which glaciers form in the Eastern Alps. Streams cascade down side valleys, along all directions of the compass, to fall into the main valleys at around $750 \mathrm{~m}$. Lakes encompassing environments which vary from high corrie to open valley adorn all the watersheds, so providing a veritable wealth of potential 
study sites. The massif is relatively unspoilt; remote from the main tourist trails; but with the occasional ski resort encroaching onto its outer fringes. The 45 lakes in the training set (Fig. 1) are located on an altitudinal gradient ranging from $1502 \mathrm{~m}$ to $2309 \mathrm{~m}$, stretching from the sub-alpine forested belt up through the lowerto the mid-alpine zone. The lakes all lie within a region stretching just $20 \mathrm{~km}$ from north to south, and $40 \mathrm{~km}$ from east to west. The 45 lakes were chosen to be as pristine as possible, while encompassing a wide spread of geographic settings, water chemistries, and basin morphologies.

\subsection{Measurements}

Kamenik et al. (2001) and Schmidt et al. (2004a, $2004 \mathrm{~b}$ ) set out the details of the training set measurements. The survey involved water chemistry, a GIS analysis of the lakes and their catchments and sky lines, lake depth and volume and water-temperature monitoring. Epilimnion water-temperatures were measured at two- and four-hourly intervals, from July 1998 to JulySeptember 1999 and from July-September 1999 to July 2003, respectively, using 8-bit MINILOG-TR thermistors (Vemco Ltd). Two thermistors per lake were deployed in water depths of 1.4 to $3.3 \mathrm{~m}$ using submerged buoys. A recovery rate of $84 \%$ (1999 and 2001) and $90 \%$ (2003) was achieved, primarily depending on weather conditions. The main loss concerned the two thermistors at Lungauer Klaffersee which were found beached above the lake shore, at turbid Oberer Landwiersee and at the large Weissensee in 1999. Lungauer Klaffersee was probably disturbed by an avalanche or land-slide. Schmidt et al. (2004a, 2004b) estimated dates of ice-out and ice-on, by visual examination of individual temperature logs, for each year and each lake. The NT lake ice-on and ice-off dates are in excellent overall agreement with those reported in Eckel's (1955) pioneering study of Austrian lakes spanning a wide altitudinal range.

A large amount of weather and climate data was obtained from nearby meteorological stations. These included (i) daily means (since 1994) of temperature and precipitation at 13 local stations, sited at elevations between 437 and $3107 \mathrm{~m}$, all within a radius of $75 \mathrm{~km}$; and (ii) daily means (since 1 Jan 1900) of temperature and precipitation at six regional stations, three at high elevation - Sonnblick, Saentis and Zugspitze, and three at low elevation, Salzburg, Munich and Vienna.

\subsection{Numerical procedures}

Multivariate analysis of the environmental variables in the training set data had been previously applied (Schmidt et al. 2004a, 2004b) using detrended correspondence analysis (DCA), correspondence analysis (CA), and canonical correspondence analysis (CCA). Also transfer functions between the biotic and environmental datasets were established using weighted aver- aging (WA), weighted averaging partial least squares (WA-PLS), and a modern analogue technique (MAT). Here we use the ordinations derived from these multivariate matrix manipulations, along with those from a principal component analysis (PCA) and a partial PCA. The ordination studies were performed using CANOCO version 4.5 (ter Braak \& Šmilauer 2002).

The main multivariate procedure employed in this study is discriminant analysis, which is a method used to distinguish between two or more categories or groups, using a weighted combination of continuous variables (Hair et al. 1998). We use the previously published ordinations, of the NT lakes, along with the physical characteristics of the lakes and their catchments as the continuous variables (or predictors) in the discriminant analysis. Lakes were allocated to five groups according to their temperature anomalies (how hot, or cold, the summer water-temperatures were for their elevation range). Discriminant analysis is used in much the same way as multiple regression, but is used to discriminate categories rather than predict a continuous variable. Here the purpose of discriminant analysis is to find the set of linear combinations of the quantitative variables that best reveals the differences among the groups.

The main numerical methods used with the water temperature and meteorological datasets were imputation, exponential smoothing (Kettle et al. 2004), and complex demodulation (Bloomfield 1976; Thompson 1995, 1999). Most time-series methods require full data sets. Consequently the very occasional missing values in our time-series were filled using the median polish algorithm of Emerson and Hoaglin (1983). The six longterm meteorological stations were used to retrodict daily temperature and precipitation throughout the last century at the 45 lakes of the NT training set; and the 13 local meteorological stations were used to generate daily values throughout the five-year period during which water temperatures were logged. In both cases multiple regression (Fox 2002) was used to interpolate the meteorological variables of interest at the lake sites. Exponential smoothing is a very simple and widely used technique. It uses a weighted average of current and past observations, with most weight to the current observation and declining weights to past observations. Complex demodulation is a data analysis technique for determining if the amplitude or generating frequency changes over the course of a single-frequency time series and so is sometimes referred to as local harmonic analysis.

\section{RESULTS}

\subsection{Thermistor records}

Excellent within-lake agreement was found for all the thermistor pairs. Many between lake similarities can also be observed. Figure 2 plots the full suite of 86 temperature time series and serves to illustrate these 


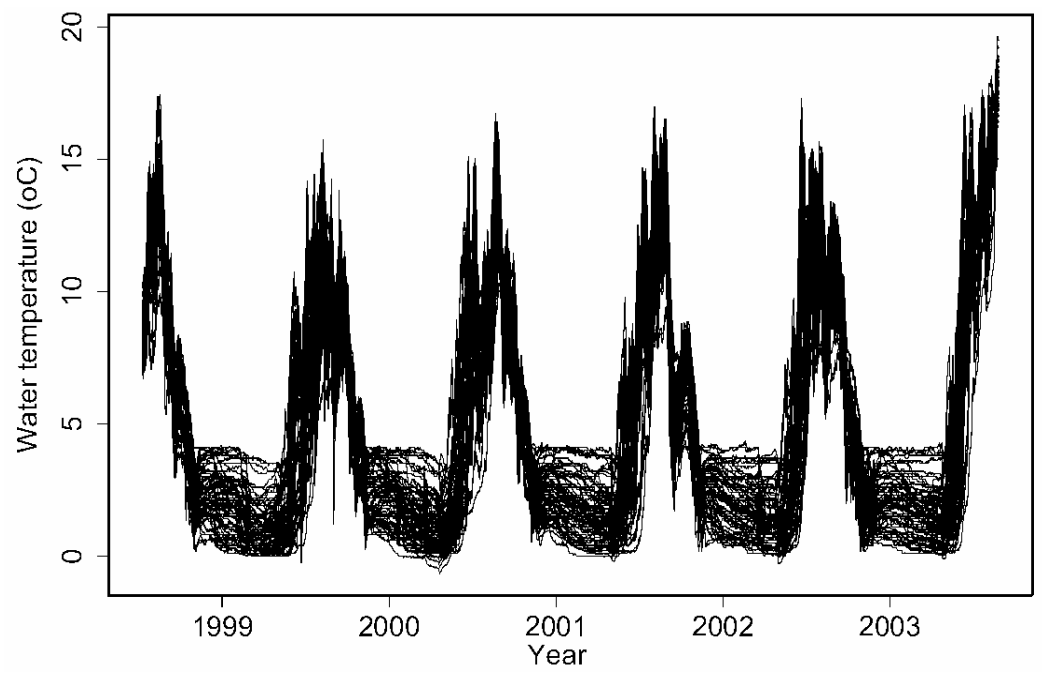

Fig. 2. Suite of thermistor logs in the epilimnion layer of the NT lakes. Daily mean temperatures are plotted for 86 thermistors.

similarities. Working through an annual cycle in figure 2, we first see that all of the NT lakes freeze in winter. Consequently the thermistor logs remain relatively steady during the winter months at temperatures of between 0 and $4{ }^{\circ} \mathrm{C}$, depending on the depth of the thermistors with respect to the ice layer. Secondly the spring thaw sees small temperature increases when the ice first breaks, or when catchment snow-melt first enters the lake. Then once the ice fully melts (ice-out), thermistor temperatures rise rapidly and begin to track the ambient air temperatures. The date of ice-out is typically 50 days earlier at the lower altitude NT lakes $(1500 \mathrm{~m})$ than at the uppermost $(2300 \mathrm{~m})$ sites. This difference in timing of ice melt leads to the ensemble of thermistor records in figure 2 following a wide swath during the spring months. Thirdly during the open-water season water-temperature fluctuations, caused by the alternating passage of warm and cold air streams, and by mixing events driven by strong winds (Thompson et al. 2005), are superimposed on the annual temperature cycle. Figure 2 illustrates how these meteorological fluctuations cause water temperature to vary in unison, with the ensemble of thermistor records following a tight, sharply defined pattern. However, each year is different. For example in summer 2001 two short, early, warm spells were followed by a cool mid-summer period before water temperatures, in all the lakes, rose to a late-summer peak. Fourthly with the onset of autumn, as soon as air-temperatures fall through the zero centigrade mark ice-on rapidly ensues. We can notice in figure 2 how the ensemble of thermistor traces follows a tighter trajectory during the autumn than in spring (esp. 2001). Overall a difference of around 30 days is observed between the dates of ice-on for the top and bottom lakes of the NT training set.

\subsection{Ice-out models}

Physically based empirical models of ice melt can be readily constructed from suites of thermistor records.
One valuable approach is to use a melting degree-day formulation. The basic idea is that days with a mean air temperature above zero centigrade encourage ice-melt, whereas those below freezing have no effect. Thus the higher the temperature, the greater is the contribution to melting. Ice-melt is modelled as occurring when the accumulating sum of the positive temperatures exceeds a critical threshold. Ruosteenoja (1986) found a melting degree-day sum of 175 degree-days worked well for large lakes in Finland, while Stewart \& Haugen (1990) determined a similar degree-day total for lakes in New York state. Agustí-Panareda \& Thompson (2002; and unpublished MOLAR report) modelled 150-year long sequences in lakes Nasijarvi and Kallavesi with a rootmean-square error of only 4 days using melting degreeday sums of 120 days. In this study we found very similar best fitting degree-day sums for the 5-year period of the NT training set.

\subsection{Ice-on models}

In many lake regions of the world the date of ice-on is determined by the seasonal fall of air temperature through the autumn months (Bilello 1964; AgustíPanareda \& Thompson 2002). Freezing degree-days provides a simple measure of accumulated cold and so can form the basis for empirical ice-on models (Bilello 1964). In the NT training set temperature sums of around 20 freezing degree-days are found to provide good relationships between air temperature and date of freeze over. Very similar totals have been determined in Canadian (Bilello 1964; Williams 1971), US (Stewart \& Haugen 1990) and Finnish (Ruosteenoja 1986; Palecki \& Barry 1986) lakes. However, it has long been recognised that ice-on also tends to reflect lake size (Wedderburn 1908). That is the larger the lake, the later the freeze over date. Stewart \& Haugen (1990) present a striking example of this effect for 22 lakes in the US. We too find that the date of ice-on is related to the lakesize. 


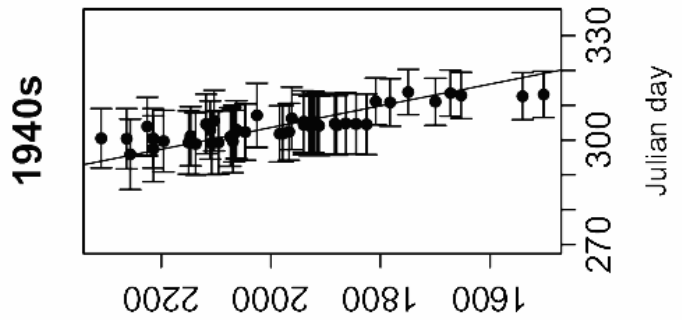

(w) นо!ฺе^ә|э

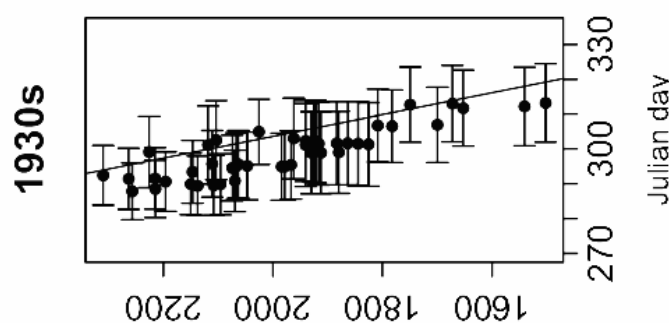

(w) นо!ฺе

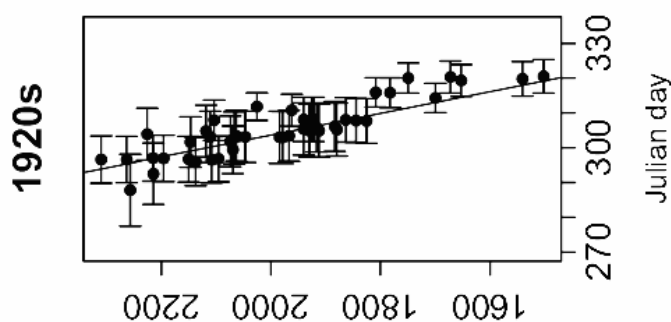

(w) ио!ฺе^ә|

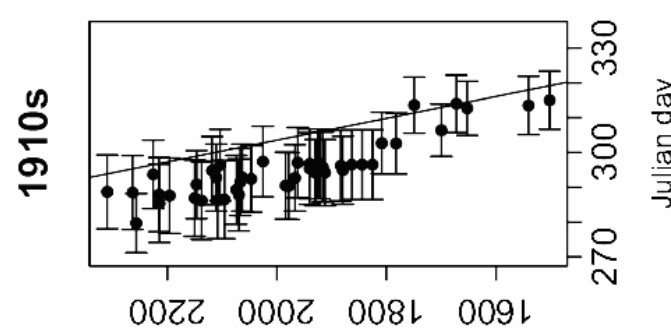

(w) чо!ฺе^ә|

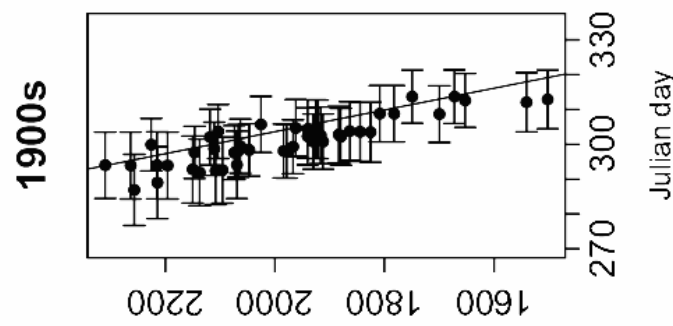

(w) ио!ฺе^ә|э

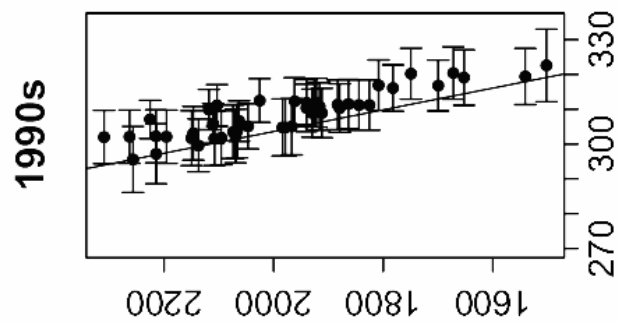

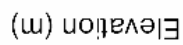

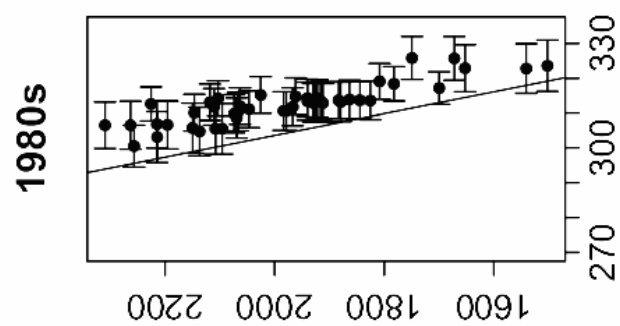

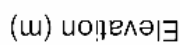

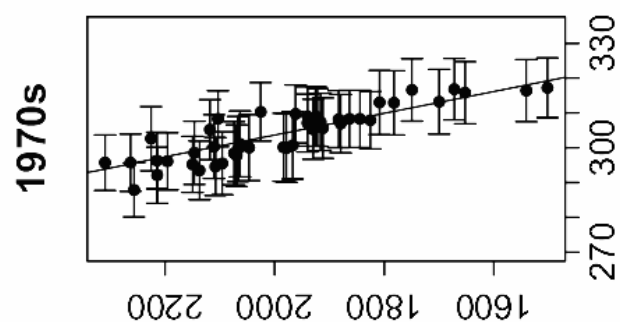

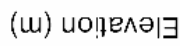

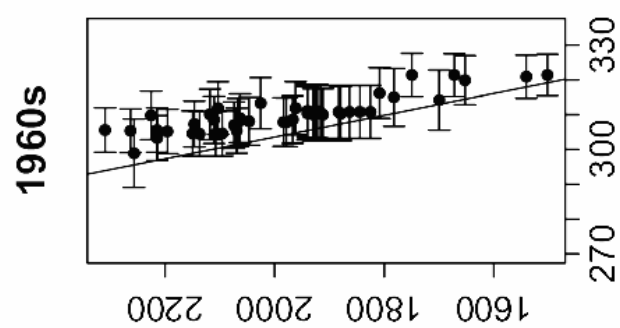

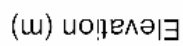

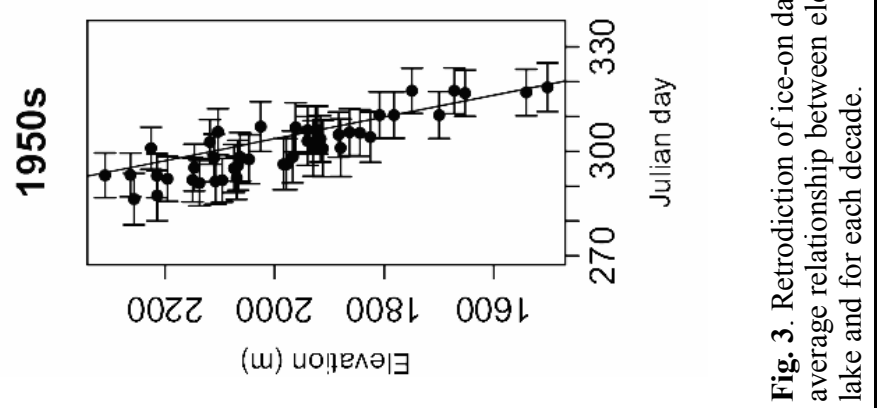




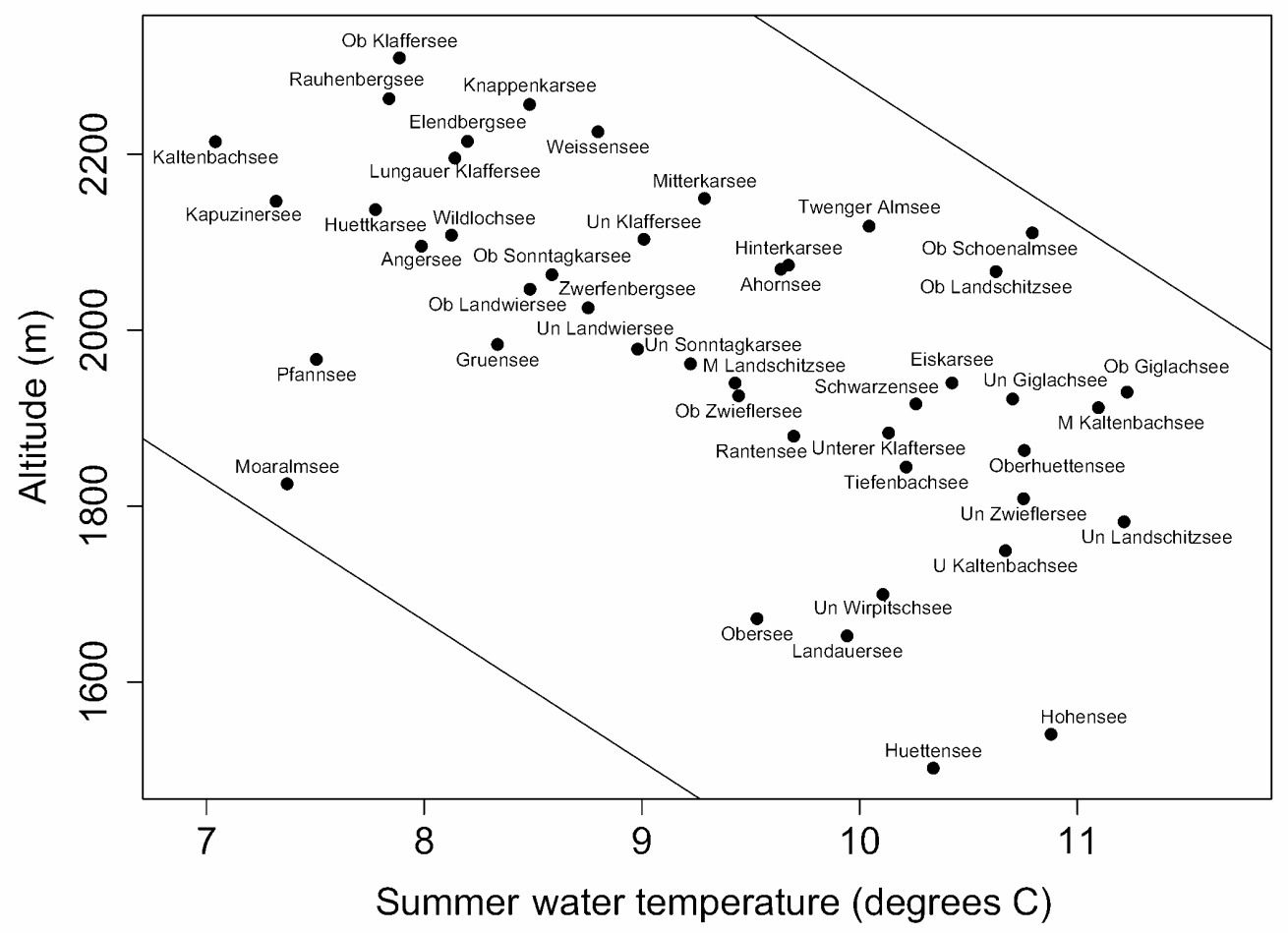

Fig. 4. Summer-epilimnion water-temperature $v s$ altitude for the 45 mountain-lakes of the Niedere Tauern training set. The two diagonal lines as drawn as approximate bounds to the 45-lake cluster. The slope of the lines follows the expected rate of change in temperature due to altitude alone $\left(-6.25^{\circ} \mathrm{C} \mathrm{km}^{-1}\right)$. We classify lakes plotting near the left hand line as being unusually cold; lakes near the right hand line as unusually hot.

Once the degree-day model parameters have been estimated for a lake region (by regression of ice-on date against lake size and the freezing degree-day threshold) it is straightforward to hindcast ice-on dates for earlier years, for which meteorological data is available. Figure 3 plots such hindcasts for the whole of the $20^{\text {th }}$ century at the 45 NT lakes. Ice-on can be seen to have occurred earlier than usual in certain decades, e.g. in the $1910 \mathrm{~s}$ and $1930 \mathrm{~s}$, when autumns were cooler than usual (Fig. 3). Ice-on is also seen to have been later than usual through the 1980s and 1990s, as a result of the pronounced warmth of recent decades. The 1940s saw very little difference in ice-on dates between the uppermost lakes and the lowermost lakes (Fig. 3). This effect can be attributed to the more continental climate of the 1940 s, when autumn temperatures fell particularly rapidly (cf. 1940s at Sonnblick - Bohm 1986; Mohnl 1994; Auer et al. 2002).

Clark \& Thompson (2004) have pointed out that the sensitivity of any degree-day model to climate change predominantly depends on the continentality of the local climate. More specifically the sensitivity (i.e., the response to a unit change in temperature) depends on the inverse of the rate of temperature change. Thus for the NT lakes where air temperatures typically fall at a rate of about $-0.17{ }^{\circ} \mathrm{C}$ per day, during the time of ice formation, a sensitivity of around 6 days per ${ }^{\circ} \mathrm{C}$ change in climate follows from the Clark-Thompson relation- ship. In contrast, in the spring, at the time leading up to ice-out on the NT lakes, air temperatures typically rise at a rate of about $0.09{ }^{\circ} \mathrm{C}$ per day. So a sensitivity of around 11 days per ${ }^{\circ} \mathrm{C}$ change in climate will hold. Thus the combined autumnal and spring thaw effects cause the open-water period of the NT lakes to extend by around 17 days for every $1{ }^{\circ} \mathrm{C}$ increase in temperature.

\subsection{Summer water-temperature}

Summer water-temperatures, like ice-on and ice-off dates, are closely related to air-temperature (Jakob et al. 1996; Livingstone \& Lotter 1998; Livingstone et al. 1999). However many more factors are involved and so interactions between the component parts of the climate system can come to the fore, exactly as alluded to by Croll (1875), and create hypersensitive relationships. Because air temperatures and water temperatures are closely related (Livingstone et al. 1999) higher elevation lakes tend to be cooler than lower elevation lakes. But water temperatures tend to lag behind air temperatures and to smooth out the higher frequency meteorological fluctuations. Exponential smoothing provides a natural means of linking water temperatures and air temperatures (Bilello 1964; Kettle et al. 2004). Lake size is found to be an important control on the smoothing process (Kettle et al. 2004). Figure 4 plots the relationship between summer water-temperature and elevation at the 45 NT lakes. To our initial surprise the 


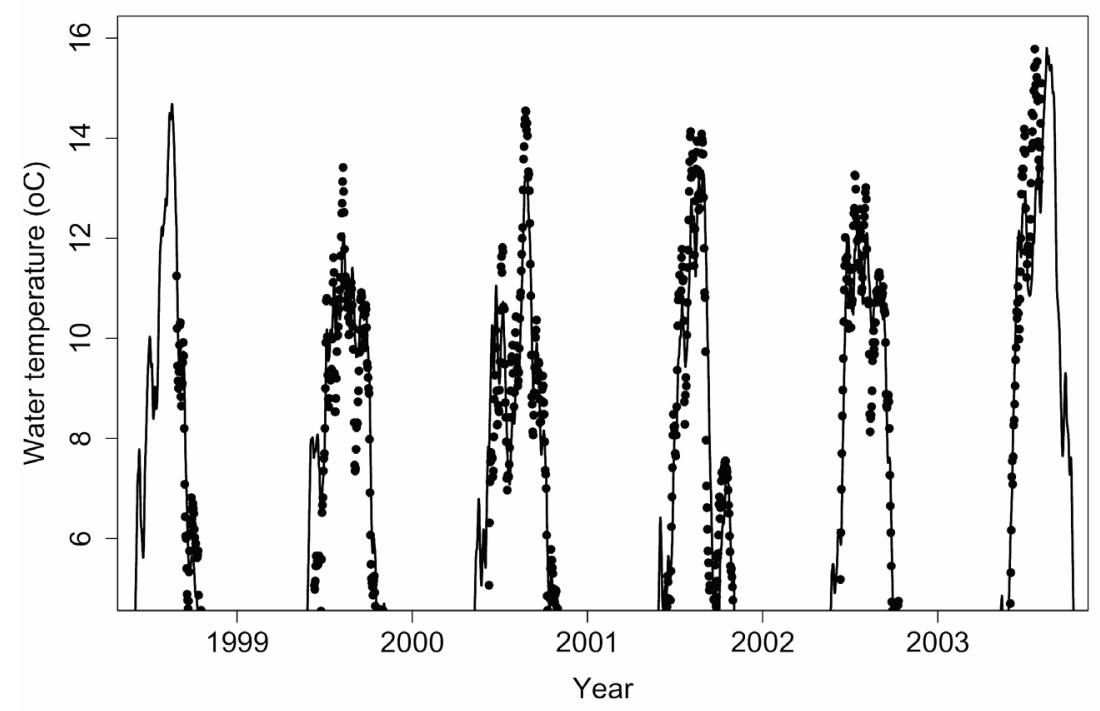

Fig. 5. Kettle et al. (2004) summer epilimnion water temperature model (solid line) applied to Lake Ahornsee daily watertemperature measurements (solid circles). The model is used to calculate water temperatures for early summer 1998 (before the thermistors were deployed) as well as late summer 2003 (after the thermistors were retrieved). The small amount of mis-fitting is caused by wind (mixing) events (e.g. late summer 1999; late summer 2002) which are not incorporated into the Kettle et al. (2004) model.

altitudinal relationship was found to be extremely poor, despite the excellent temporal coherence in water temperatures observed between the NT lakes throughout the 5-year monitoring period (Fig. 2).

Turning to the weather data; the 13 local meteorological stations demonstrated that a straightforward linear lapse-rate of summer (JJA) air-temperatures pertained throughout monitoring period, exactly as expected for the Austrian Alps (Auer \& Bohm 1994). The diagonal lines of figure 4 are drawn to parallel to this summer lapse-rate. How then are the different altitudinal relationships between the water and air temperatures to be explained? With this question in mind we first made extensive checks on the water temperature data. The very strong within- and between-lake reproducibility of the records convinced us that all the water temperature records were reliable, and of high quality, and that the wide scatter in figure 4 was real. As possible causes of the scatter we next investigated (i) the effect of lake size, and its control on the exponential smoothing parameter in the Kettle et al. (2004) model, and (ii) direct shading of the lakes. Exponential smoothing was found to provide excellent fits between water temperature and air temperature at individual lakes. To give just one example: figure 5 presents the fit, at the first lake in our data set - Ahornsee. The interannual differences in water temperature are well modelled, as are the week-by-week fluctuations. But no simple relationship between lake depth, or lake area, and the exponential smoothing parameters was found for the NT region as a whole. Similarly the unusually cold lakes in figure 4, (e.g. Moaralmsee and Pfannsee) were not found to be directly shaded from the sun.
Instead other potential causes of the wide range of summer water-temperature, within any given elevation range were sought.

We can sub-divide the NT lakes into five groups by making the assumption that the rate of decrease of air temperature with elevation (the slope of the diagonal lines in Fig. 4) is also the expected, or typical, rate of decrease for water temperature. Under this assumption we classify six lakes of the NT lakes (Moaralmsee, Hüttensee, Pfannsee, Obersee, Hohensee, Landauersee) as being unusually cold; four lakes (Unterer Wirpitschsee, Grünsee, Kapuzinersee, Kaltenbachsee) as cool; 26 lakes as normal; six lakes (Oberer Giglachsee, Ahornsee, Hinterkarsee, Mitterkarsee, Weissensee, Knappenkarsee) as warm; and finally Twenger Almsee, Oberer Landschitzsee, Oberer Schönalmsee as three unusually hot lakes. Under this classification scheme Moaralmsee is the most extreme lake. We found it particularly instructive to compare the water temperature traces at Moaralmsee with those logged in NT lakes of a similar size and at a similar altitude (Fig. 6). Ice-on and ice-off dates were found to be similar at all the lakes. In figure 6 ice-break at Moaralmsee is seen to be slightly the earliest due to it's somewhat lower, and hence, warmer setting. However, instead of the lakes having similar summertime water-temperatures, Moaralmsee is seen to be much the colder. While the Oberer Landschitzsee and Oberer Giglachsee temperatures of figure 6 track one another closely, summer water-temperatures at Moaralmsee are generally 6 to $7{ }^{\circ} \mathrm{C}$ cooler $\left(4\right.$ to $5{ }^{\circ} \mathrm{C}$ cooler in summer 2000). We also observed Pfannsee and Gruensee to show very similar discrepancies in water termperature; as does Obersee with respect to its 


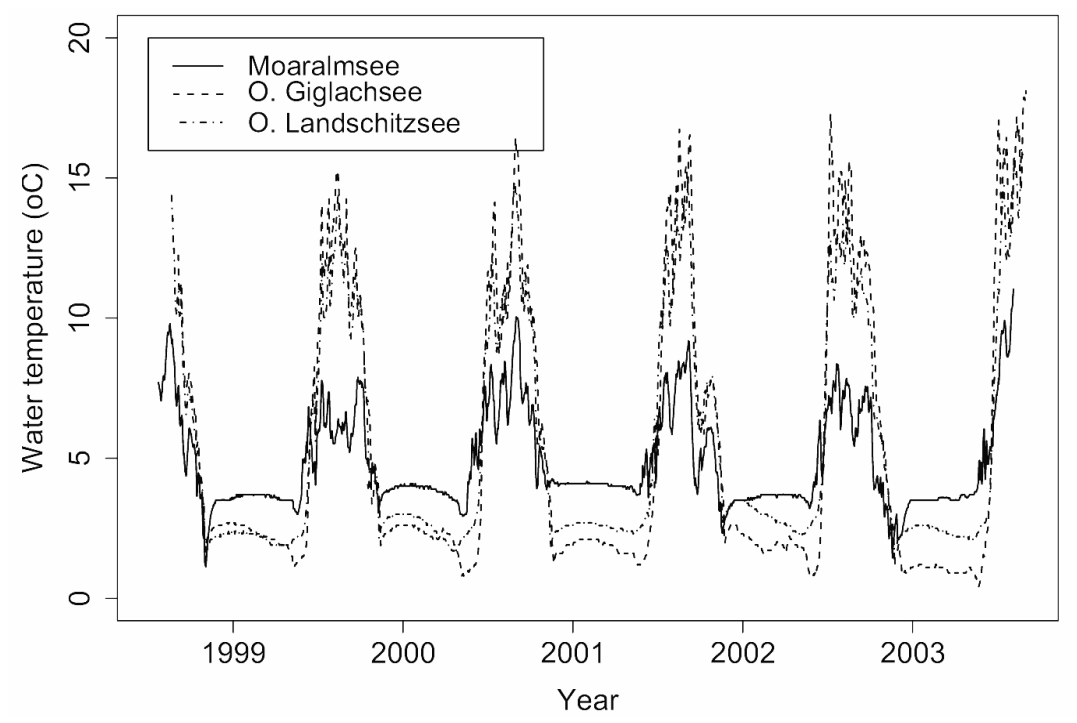

Fig. 6. Moaralmsee: an example of a lake with unusually cold early- and mid-summer epilimnion water temperatures. Moaralmsee has a maximum length of $232 \mathrm{~m}$ and a maximum width of $127 \mathrm{~m}$. The Moaralmsee thermistor $\log$ (from near the middle) is contrasted with logs from two comparable lakes at a similar altitude. Differences in winter temperatures are attributed to slight differences in the below ice depth of the thermistors in the various lakes. The three lakes have similar altitudes and so their dates of ice-on and ice-off are very similar. We attribute the unusually cold summer water-temperatures at Moaralmsee to snow melt. Note how in summer 1999 the Moaralmsee water temperatures are coldest when the other lakes are at their warmest.

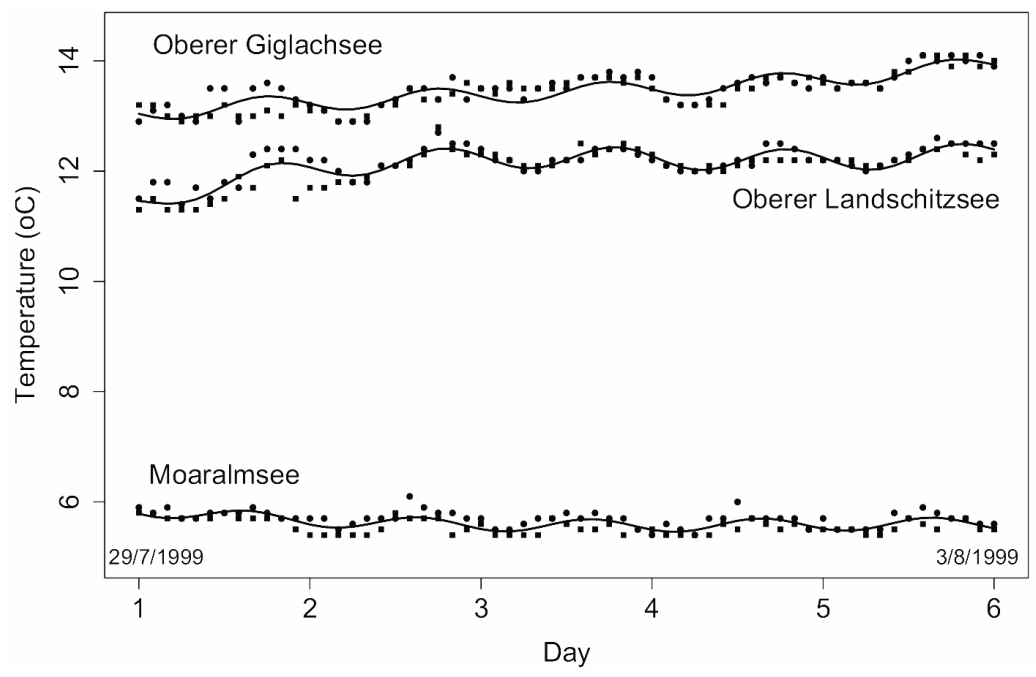

Fig. 7. Diurnal variation of epilimnion water temperature at Moaralmsee, Oberer Giglachsee and Oberer Landschitzsee in early summer 1999. Thermistor 1, circles: thermistor 2, squares. The smooth curves emphasise the diurnal cycle. Although the three lakes are of similar size and altitude, Moaralmsee is much colder, is cooling rather than warming and has a suppressed, phase-shifted diurnal temperature cycle.

closest morphological and altitudinal equivalent lake, namely Unterer Landschitzsee. Springtime and autumn temperatures at Moaralmsee while cooler than those at the other two lakes, are not as discrepant as in summer (Fig. 6). A summer flowthrough of cool water, either from groundwaters or snowmelt, could explain many of the differences. Moaralmsee is well separated from the corrie back-wall to its south by an upper basin and an intervening large moraine field and consequently is largely groundwater fed. However, closer inspect of figure 6 reveals that Moaralmsee water-temperatures decrease when air temperatures increase. This distinc- tive signature favours snowmelt as the most likely cause of the temperature discrepancies (Hock 2003; Verbunt et al. 2003). A final result which further emphasises the likely importance of snow melt is shown in figures 7 and 8, where two-hourly data for six day sequences at Moaralmsee, in early summer and early autumn 1999, along with that from two comparable sites, is plotted. If rising air temperatures were indeed causing snow-melt and hence an enhanced cold water through-flow then a particularly pronounced effect might be anticipated in the late-afternoon. Figure 7 reveals the anticipated phase shift in the Moaralmsee time-series. Furthermore, 


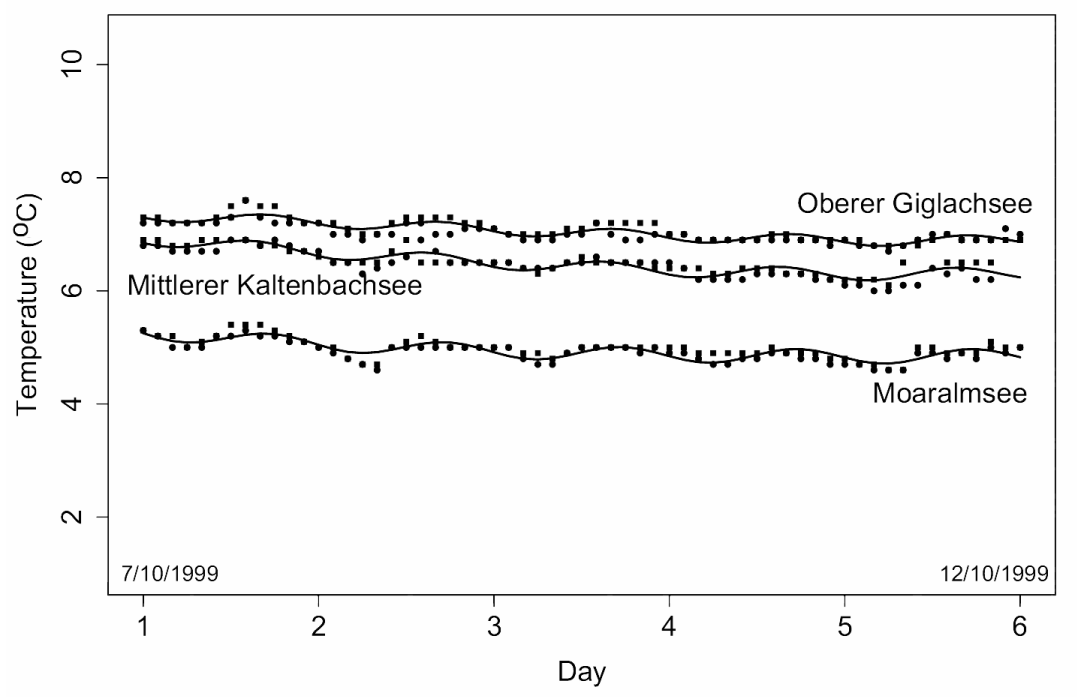

Fig. 8. Diurnal variation of epilimnion water temperature at Moaralmsee, Oberer Giglachsee and Mittlerer Kaltenbachseee in autumn 1999. Symbols and curves as Fig. 7. At this time of year these three lakes, of similar size and altitude, all show similar temperatures, temperature trends and diurnal temperature cycles.

the overall rising trend at Oberer Landschitzsee and Oberer Giglachsee of around 0.14 degrees per day appears to completely masked at Moaralmsee by the snow-melt effect. Figure 8, by way of contrast, plots an autumnal six-day sequence. Our interpretation is that by late autumn the snow has all but disappeared from the upper slopes and shaded gullies of the Moaralmsee catchment and so its phase relationships and general temperature trend are fully synchronised with the other lakes. In early autumn 2004 three small snow patch remanents could be observed in gullies on the NE facing headwalls. Finally we note that the diurnal temperature effects we attribute to snow-melt (Fig. 7) are of only a fraction of one degree, although the temperature of the snow-melt waters are likely some ten degrees cooler than those of the lake. These relative magnitudes are not unexpected for a lake of the size of Moaralmsee, with a residence time of many days.

\subsection{Multivariate analysis}

Multivariate analysis of the training set data allows the factors controlling, or influenced by, snow-melt and the unusually cold lake water-temperatures to be investigated. Kamenik et al. (2001) have previously shown that the NT lake water-chemistry can be summarized with two principal components (PC). PC axis 1 was related to carbonate weathering. $\mathrm{PC}$ axis 2 represented in-lake productivity (trophy).

A first qualitative comparison of these previously obtained ordinations with our five temperatures groupings cold/cool/normal/warm/hot produced no association with PC1. However temperature anomaly and PC2 showed more affinity. Consequently we proceeded to a more formal analysis. The analysis included the shape, size and geographical setting of the lakes as additional predictors. We found that a good separation of the five lake-temperature groupings is achieved in a discriminant analysis (Fig. 9). The five dominant predictors were found to be southwest and northeast aspect (based on percentage of catchment area facing the NNW-toENE and WSW-to-SSE), trophy (PC axis 2), lake-area and volume. The first linear discriminant (LD1) serves to distinguish the anomalously hot/warm lakes from the anomalously cool/cold lakes (Fig. 9). Table 1 tabulates the group means, coefficients of the first three linear discriminants, and the proportion of the trace (product of the relevant covariance matrices) for which the linear discriminants account. Tables $1 \mathrm{a}$ and $1 \mathrm{~b}$ highlight the importance of the direction in which catchments face. In comparison with some other studies direct solar radiation did not show up as an important control on lake water-temperatures in any of our multivariate work. In summary the main overall finding from the multivariate analyses was that small, oligotrophic, north-east facing lakes tended to be cooler than larger, more trophic, lakes in catchments with a south-westerly aspect.

The tendency for trophy to be associated with warmer waters in the NT lakes is somewhat counter intuitive as the opposite association is found in the oceans, and large lakes, using satellite data from the Advanced Very High Resolution Radiometer missions (Denman \& Abbott 1994). Gabathuler (1999) has assessed the effects of turbulence, albedo and water colour on mountain lakes in the Jorisee region of Switzerland. In addition to lake depth he notes the important role of turbidity, and points out that in particle rich lakes the euphotic depth (where light intensity falls to $1 \%$ of that at the surface and is no longer sufficient for photosynthesis) is around $4 \mathrm{~m}$, whereas in clear 


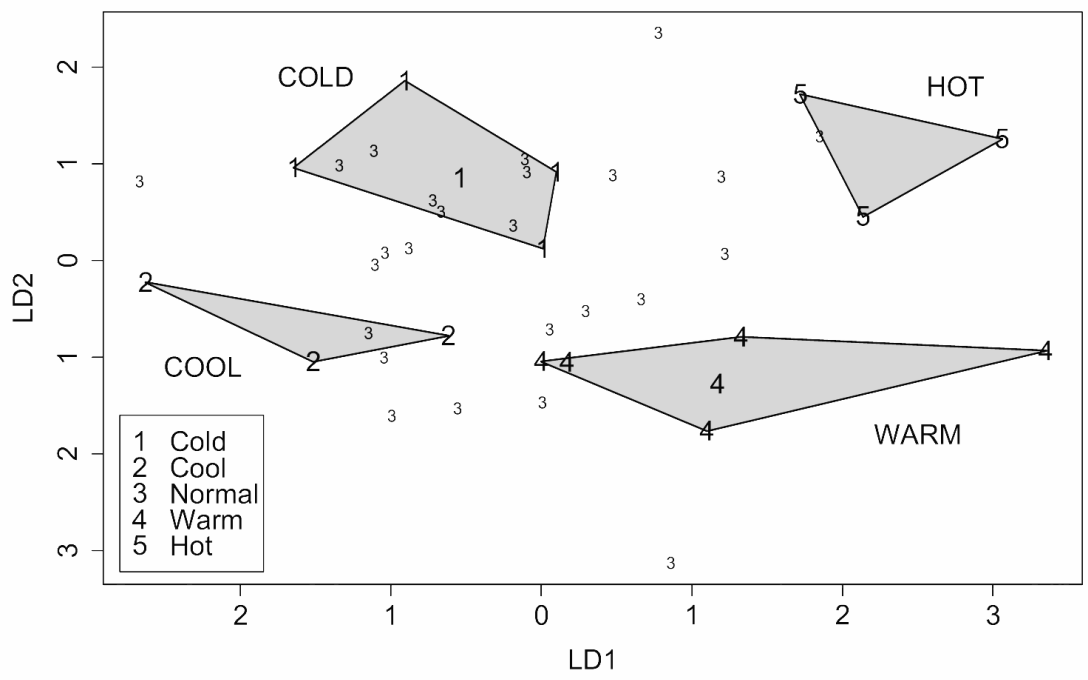

Fig. 9. Linear discriminant analysis of five classes of lake: $1=$ cold, $2=$ cool, $3=$ normal, $4=$ warm and $5=$ hot. The main linear discriminants were found to be PCA axis- 2 (which characterizes trophy), lake area, lake volume, proportion of catchment facing northeast and proportion of catchment facing southwest.

Tab. 1. Discriminant analysis.

(a) Group means: the mean discriminant scores for each temperature grouping.

\begin{tabular}{cccccl}
\hline Grouping & Southwest & Northeast & PC2(trophy) & Area & Volume \\
\hline Cold & -0.57 & 0.34 & -0.37 & 0.077 & -0.09 \\
Cool & -0.16 & 0.29 & -0.37 & -0.77 & -0.67 \\
Normal & -0.17 & 0.16 & -0.13 & 0.13 & 0.17 \\
Warm & 0.93 & -0.63 & 0.57 & -0.34 & -0.26 \\
Hot & 0.76 & -1.1 & 1.1 & 0.47 & 0.11 \\
\hline
\end{tabular}

(b) Coefficients of linear discriminants, which maximize the distance between the means of the five temperature groupings.

\begin{tabular}{lccc}
\hline Predictors & LD1 & LD2 & LD3 \\
\hline Southwest & 1.1 & -1.5 & -0.48 \\
Northeast & 0.14 & -1.6 & -0.54 \\
PC2(trophy) & 0.83 & 0.13 & -0.11 \\
Area & -0.14 & 1.4 & 0.64 \\
Volume & 0.09 & -0.70 & -1.4 \\
\hline
\end{tabular}

(c) Proportion of trace: an indication of the relative discriminating power of the first three linear discriminants.

\begin{tabular}{lll}
\hline LD1 & LD2 & LD3 \\
0.65 & 0.29 & 0.05 \\
\hline
\end{tabular}

lakes it is often greater than the maximum depth of the lake. The bottom conditions of mountain lakes, unlike the oceans, can thus be of relevance to the energy balance and water temperature.

\section{DISCUSSION}

\subsection{Climate sensitivity}

The poor association between summer water-temperature and altitude in the NT training set lakes, which initially caused us surprise, can be turned to our advan- tage. Now that we attribute the water temperatures to a combination of altitudinal and snow-melt effects, the training set can be used to furnish us with quantitative estimates of the sensitivity of the NT lakes to climate change. This sensitivity can in-turn provide a means of obtaining projections of the impact of future global change on the NT lakes. The altitude of an alpine lake turns out to be of critical importance in determining its sensitivity to climate change. In the case of ice-cover duration: lakes at low elevations never freeze and so are insensitive to temperature changes. Similarly lakes at 
high elevations are permanently frozen and so again are insensitive, as they require a large temperature increase before any melting can occur. However lakes at intermediate altitudes can be very sensitive. Thompson et al. (2005) have modelled ice-cover sensitivity for a range of climate change scenarios and a range of altitudes. Austrian lakes at altitudes of between 1500 and $2000 \mathrm{~m}$ are found to occupy a zone of maximum impact, where a one degree temperature change causes as much as a 30 day change in ice-cover duration. An equivalent situation pertains in the case of snow-cover. Air-temperature is once again found to be the dominant controlling factor (Beniston 1997; Wielke et al. 2004), although there is also some tendency for deeper than average snow accumulation to be associated with wet winters (Beniston et al. 2003a, b). Hantel et al. (2000) describe how at low elevations it takes a large decrease in temperature before any snow can occur, and how mountain tops have permanent snow cover and so they too are insensitive to long-term temperature change or interannual vacillations in temperature, but how strong temperature responses are found at intermediate elevations. The altitude of the zone of maximum sensitivity in snow cover duration varies through the year. It is lowest in winter and highest in summer. In Austria Hantel et al. (2000) find the strongest wintertime effect occurs at around 500 $\mathrm{m}$ where snow-cover duration can decrease by over 30 days due to a one-degree mean temperature rise. Breiling \& Charamza (1999) point out that this sensitivity makes the lower elevation ski resorts of Austria, with their dependence on winter 1-day visitors from neighbouring cities, very vulnerable to climate change. An analogous situation pertains in Switzerland (Wielke et al. 2004; Beniston et al. 2003a). As spring arrives the sensitive zone begins to ascend, along with the zero-degree isotherm. Hantel et al. (2000) place the spring maximum at $1500 \mathrm{~m}$ where sensitivities as high as 42 days snow cover per degree of temperature change occur. Breiling (1998) points out that Alpine communities and ski areas at these intermediate elevations will need to make increasingly heavy investments in snow making facilities if they are to adapt to increases in climate warmth and variability. Just as future climate change will have important economic consequences for some intermediate elevation ski-areas, it will have important ecological consequences for intermediate elevation catchments. Lakes like Huettensee, Hohensee and Moaralmsee are particularly susceptible to climate change, because as the climate warms they will be subjected to three strong effects. Not only will they (i) see marked reductions in the springtime snow-cover of their immediate surroundings, but (ii) they will be subjected to particularly pronounced increases in their open-water season, and (iii) their upper catchments will lie in the zone in which summer snow cover will become rare, and consequently snow melt effects will become much less prevalent.

\subsection{Climate impact}

Schär et al. (2004) have drawn attention to a likely enhancement of temperature change over central Europe, along with a much increased variability. They note how temperature and precipitation changes must always be regarded as coupled variables and how temperature changes depend on the proportions of latent and sensible heat flux as modulated by the meso-scale atmospheric circulation. They point out that as the climate of central and southern Europe takes on a drier more Mediterranean pattern, the plants and soils will lose their moisture. As a consequence less energy will be expended on evaporation allowing more heating of the air to take place so fostering a propensity of worsening summer heat-waves. Their regional computer climate simulations, for the end of this century, point to every second summer being as hot and as dry as the extreme summer of 2003. This regional effect, caused by a semi-arid climate bordering a wetter region, will probably see maximum changes in central and eastern Europe with summer temperatures five to six degrees higher than present (Fig. 3c in Schär et al. 2004), reduced summer precipitation, and major shifts in the discharge regimes of snow fed rivers. Projections based on the HadCM3 coupled atmosphere-ocean general circulation model (Pope et al. 2000) show similar temperature and precipitation changes (Liszewska \& Marzena 2002). The total impact of climate change on a lake depends on the product of the lake sensitivity and the magnitude of the local climate-change. Several of the NT lakes are likely to be hypersensitive to future global change because as well as being highly sensitive to the three effects described above, they can in addition be expected to be subjected to an enhanced regional climatic change.

Taking together all the climate change effects discussed above, we can reflect on the type of water bodies that the anomalously cold, oligotrophic, NT mountain-lakes such as Moaralmsee, Pfannsee and Huettensee might evolve into. Following the Schär et al. (2004) prognosis for climate change in the Alpine region a five- or six-degree increase in air-temperatures can be anticipated by the end of the century. With "lapse rates" of around $6{ }^{\circ} \mathrm{C} \mathrm{km}^{-1}$, snow-lines will likely rise about $1000 \mathrm{~m}$. As a consequence the cooling effects of summer snowfields whose melting currently causes a four to six degrees lowering of water temperatures in many NT lakes will be substantially reduced or disappear (Rango \& Martinec 1993; Hock 2003; Verbunt et al. 2003). The combination of an increase in air-temperature (of around six-degrees), with a further four- to six-degree increase from the absence of snowmelt, indicates that the surface waters of the most ultrasensitive NT lakes are likely to warm by $12{ }^{\circ} \mathrm{C}$ in the coming century.

Goggausee, a well studied, Carinthian valley-lake, at an altitude of $780 \mathrm{~m}$, provides one present-day analogue 
of the thermal characteristics that the medium altitude Tauern lakes might evolve towards. It has summer water-temperatures of around $20{ }^{\circ} \mathrm{C}$ and a more Mediterranean influenced climate (Brenner 1975). However, it seems unlikely that the nutrient and phosphorous loading in the NT lakes will change in the coming century to Goggausee levels, as the local timber-lines and soils will need more time to adjust to future climate change (Dullinger et al. 2004). Instead the NT lakes are likely to evolve into a no-analogue state.

\section{CONCLUSIONS}

- The high sensitivity of the alpine lakes is caused by: their positioning in an altitudinal zone within which ice-cover duration is strongly modulated by temperature; the effect of summertime snow-melt in north-facing catchments is particularly sensitive; the relatively small size of the lakes; and the general setting of the Alps in a region, where temperature increases are likely to be enhanced by increases in year-to-year variability associated with reduced summer precipitation, drier soils and changes to the Bowen ratio.

- We use the air vs. water temperature relationships to evaluate the climate sensitivity of the NT lakes as well as its potential impact. Based on a local warming of 5 to 6 degrees in summer air temperatures, combined with a further 6 degree warming caused by the absence of the current snowmelt effect, we deduce that the surface waters of our most sensitive lakes are likely to warm by around $12{ }^{\circ} \mathrm{C}$ in the coming century.

- Global change will cause many alpine lakes, and their freshwater ecosystems, to evolve this century into no-analogue systems.

\section{ACKNOWLEDGEMENTS}

We obtained data from Infospace, ECA (the European Climate Assessment) and NCDC (the National Climatic Data Center). We are most grateful for their www sites. The detailed lake and catchment GIS data were provided by Georg Kum. We would like to thank P. Indinger, E. Lukas and numerous volunteers for their help in the field. The background studies were funded by the Austrian Science Fund (FWF, project no. P14912-B06). The Royal Society of London kindly funded a short study visit by RT to the Institute of Limnology of the Austrian Academy of Sciences, so allowing this research work to be undertaken.

\section{REFERENCES}

Agustí-Panareda, A. \& R. Thompson. 2002. Reconstructing air temperature at eleven remote alpine and arctic lakes in Europe from 1781 to 1997 AD. J. Paleolimnol., 28: 7-23.

Auer, I. \& R. Böhm. 1994. Combined temperatureprecipitation variations in Austria during the instrumental period. Theoretical and Applied Climatology, 49: 161-174.
Auer, I., R. Böhm, M. Leymüller, W. Schöner, A. Kaiser, H. Scheifinger, M. Langer, S. Schneider \& C. Häberli. 2002. Das Klima des Sonnblicks. Klimaatlas und Klimatographie der GAW Station Sonnblick einschliesslich der umgebenden Gebirgsregion. Oesterreichische Beiträge zu Meteorologie und Geophysik. Heft 28: 304 pp.

Battarbee, R.W., F. Gasse \& C.E. Stickley (Eds). 2004. Past Climate Variability through Europe and Africa. Kluwer Academic Publishers, Dordrecht, the Netherlands: $638 \mathrm{pp}$.

Beniston, M. 1997. Variations of snow depth and duration in the Swiss Alps over the last 50 years: links to changes in large-scale climatic forcings. Climate Change, 36: 281-300.

Beniston, M., F. Keller, S. Goyette. 2003a. Snow pack in the Swiss Alps under changing climatic conditions: an empirical approach for climate impacts studies. Theoretical and Applied Climatology, 74: 19-31.

Beniston, M., F. Keller, B. Koffi \& S. Goyette. 2003b. Estimates of snow accumulation and volume in the Swiss Alps under changing climatic conditions. Theoretical and Applied Climatology, 76: 125-140

Bilello, M.A. 1964 Method for predicting river and lake ice formation. Journal of Applied Meteorology, 3: 38-44.

Birks, H.J.B. 1998. Numerical tools in palaeolimnology Progress, potentials, and problems. J. Paleolimnol., 20: 307-332.

Bloomfield, P. 1976. Fourier Analysis of Time Series. John Wiley and Sons, New York: $258 \mathrm{pp}$.

Bohm, R. 1986. Der Sonnblick. Die 100 jahrige Geschichte des Observatoriums und seiner Forschungstatigkeit. Vienna, 0sterreichischer Bundesverlag: $224 \mathrm{pp.}$

ter Braak, C.J.F. \& P. Šmilauer. 2002. CANOCO reference manual and CanoDraw for Windows user's guide: software for canonical community ordination (version 4.5). - Microcomputer Power, Ithaca NY, USA.

Breiling, M. 1998. The role of snow cover in Austrian economy during 1965 and 1995 and possible consequences under a situation of temperature change. Conference Japanese Society of Snow and Ice. October 1998.

Breiling, M. \& P. Charamza. 1999. The impact of global warming on winter tourism and skiing: a regionalised model for Austrian snow conditions. In: Regional Environmental Change. 1. Springer Verlag, Berlin: 4-14.

Brenner, 1975 (see http://www.umwelt.ktn.gv.at/ Seenbericht/ goggausee/mitte.htm)

Clark, R.M. \& R. Thompson. 2004. Global warming gives flowering plants a boost. Australasian Science (October): 37-38.

Croll, J. 1875. Climate and time in their geological relations: a theory of secular changes of the earth's climate. London: Daldy, Isbister: $577 \mathrm{pp}$.

Denman, K.L. \& M.R. Abbott. 1994. Time scales of pattern evolution from cross-spectrum analysis of AVHRR and CZCS imagery. Journal Geophysical Research, 99: 74337442.

Dullinger, S., T, Dirnböck, \& G. Grabherr. (2004) Modelling climate change-driven treeline shifts: relative effects of temperature increase, dispersal and invasibility. J. Ecol., 92: 241-252.

Eckel, O. 1955 Statistisches zur Vereisung der Ostalpenseen. Wetter und Leben, Heft 3-4: 49-56.

Emerson, J.D. \& D.C. Hoaglin. (1983) Analysis of two-way tables by medians. In: D.C. Hoaglin, F. Mosteller, and J.W. Tukey, (Eds), Understanding robust and exploratory data analysis. John Wiley \& Sons, New York: p. 166-207.

Fee, E.J., J.A. Shearer, E.R. DeBruyn \& E.U. Schindler (1992) Effects of lake size on phytoplankton photosynthesis. Can. J. Fish. aquat. Sci., 49: 2445-2459

Fox, J. 2002. An $R$ and S-PLUS Companion to Applied Regression. Sage: $312 \mathrm{pp}$. 
Gabathuler, M. 1999. Physical ecosystem determinants in high mountain lakes - the Joeri Lakes (Switzerland). Diss. ETH Zurich. Swiss Federal Institute of Technology, Institut for atmosphere physics, Zurich.

Gray, D.M. \& D.H. Male (Eds) 1981. The handbook of snow, Pergamon Press: $776 \mathrm{pp}$

Gerten, D. \& R. Adrian. 2002. Effects of climate warming, North Atlantic Oscillation, and El Niño-Southern Oscillation on thermal conditions and plankton dynamics in Northern Hemispheric lakes. The Scientific World Journal, 2: 586-606.

Hair, J.F., Jr., R.E. Anderson, R.L. Tatham, \& W.C. Black. 1998. Multivariate Data Analysis, 5th edition. Upper Saddle River, New Jersey. Prentice-Hall, Incorporated: $730 \mathrm{pp}$.

Hantel, M., Ehrendorfer, M., \& A. Haslinger. 2000. Climate sensitivity of snow cover duration in Austria. International Journal of Climatology, 20: 615-640.

Hock, R. 2003. Temperature index melt modelling in mountain areas. J. Hydrol., 282: 104-115.

Houghton, J.T., Meiro Filho, L.G., Callander, B.A., Harris, N., Kattenberg, A. \& Maskell, K. (Eds). 1996. Climate Change 1995: The Science of Climate Change. Cambridge University Press, Cambridge: $572 \mathrm{pp}$.

Houghton, J.T. Meiro Filho, L.G., Callander, B.A., Harris, N., Kattenberg, A. \& Maskell, K. (Eds). 2001. Climate Change 2001: The Scientific Basis. IPCC (Intergovernmental Panel on Climate Change), Cambridge University Press, Cambridge: $881 \mathrm{pp}$.

Imbrie, J. \& N. Kipp. 1971. The Agulhas Current during the Late Pleistocene: Analysis of modern faunal analogs. Science, 207: 64-66.

Jakob, A., P. Liechti \& B. Schädler. 1996. Temperatur in Schweizer Gewässern Quo vadis? Gas Wasser Abwasser, 76: 288-294.

Jones, P.D., M. New, D.E. Parker, S. Martin \& I.G. Rigor. 1999. Surface air temperature and its changes over the past 150 years. Reviews of Geophysics, 37: 173-199.

Jones, P.D. \& A. Moberg. 2003. Hemispheric and large-scale surface air temperature variations: An extensive revision and an update to 2001. Journal of Climate, 16: 206-223.

Kamenik, C., R. Schmidt, G. Kum \& R. Psenner. 2001. The influence of catchment characteristics on the water chemistry of mountain lakes. Arctic Antarctic and Alpine Research, 33: 404-409.

Kettle, H., R. Thompson, N.J. Anderson \& D.M. Livingstone. 2004. Empirical modeling of summer lake surface temperatures in southwest Greenland. Limnol. Oceanogr., 49: 271-282.

Liszewska, M. \& O. Marzena. 2002. Climate changes in Central Europe projected by general circulation models. GeoJournal, 57: 139-147.

Livingstone, D.M. \& A.F. Lotter. 1998. The relationship between air and water temperatures in lakes of the Swiss Plateau: a case study with palæolimnological implications. J. Paleolimnol., 19: 181-198.

Livingstone, D.M., A.F. Lotter \& I.R. Walker. 1999. The decrease in summer surface water temperature with altitude in Swiss Alpine lakes: a comparison with air temperature lapse rates. Arctic, Antarctic and Alpine Research, 31: 341-352.

Mohnl, H. 1994. Die Schwankungen der Neuschneehöhe und Schneedeckendauer in Osterreich (Periode 1895-1992). In: 90.-91. Jahresbericht des Sonnblick ereins für die Jahre 1992-1993. Eigenverlag des Sonnblickvereins, Wien.

Palecki, M.A. \& R.G. Barry. 1986. Freeze-up and break-up of lakes as an index of temperature changes during the transition seasons: A case study for Finland. Journal Climate and Applied. Meteorology, 25: 893-902.
Petit, J.R., J. Jouzel, D. Raynaud, N.I. Barkov, J.-M. Barnola, I. Basile, M. Benders, J. Chappellaz, M. Davis, G. Delayque, M. Delmotte, V.M. Kotlyakov, M. Legrand, V.Y. Lipenkov, C. Lorius, L. Pépin, C. Ritz, E. Saltzman, $\&$ M. Stievenard. 1999. Climate and atmospheric history of the past 420,000 years from the Vostok ice core, Antarctica. Nature, 399: 429-436.

Pope, V.D., M.L. Gallani, P.R. Rowntree \& R.A. Stratton. 2000. The impact of new physical parametrizations in the Hadley Centre climate model -- HadAM3. Climate Dynamics, 16: 123-146.

Rango, A. \& J. Martinec. 1994. Areal extent of snow cover in a changed climate. Nordic Hydrology, 25: 233-246.

Regier, H.A., J.A. Holmes \& D. Pauly. 1990 Influence of temperature changes on aquatic ecosystems: an interpretation of empirical data. Trans. Am. Fish. Soc., 119: 374389.

Ruosteenoja, K. 1986. The date of break-up of lake ice as a climatic index. Geophysica, 22: 89-99.

Schär, C., P.L. Vidale, D. Luthi, C. Frei, C. Haberli, M.A Liniger \& C. Appenzeller. 2004. The role of increasing temperature variability in European summer heatwaves. Nature, 427: 332-336.

Schmidt, R., C. Kamenik, C. Kaiblinger \& M. Hetzel. 2004a. Tracking Holocene environmental changes in alpine lake sediment core: application of regional diatom calibration, geochemistry, and pollen. J. Paleolimnol., 32: 177-196.

Schmidt, R., C. Kamenik, R. Klee \& H. Lange-Bertalot 2004b. Fragilaria and Staurosira (Bacillariophyceae) from sediment surfaces of 40 lakes in the Austrian Alps in relation to environmental variables, and their potential for palaeoclimatology. J. Limnol., 63: 171-189.

Shuter, B.J. \& K.K. Ing. 1997. Factors affecting the production of zooplankton in lakes. Can. J. Fish. aquat. Sci., 54: 359-377.

Stenni, B., V. Masson-Delmotte, S. Johnsen, J. Jouzel, A. Longinelli, E. Monnin, R. Röthlisberger \& E. Selmo. 2001. An oceanic cold reversal during the last deglaciation. Science, 293: 2074-2077.

Stewart, K.M. \& R.K. Haugen. 1990. Influence of lake morphometry on ice dates, Verh. int. Ver. Theor. Angew. Limnol., 24: 122-127.

Stramski, D. \& D.A. Kiefer. 1991. Light scattering by microorganisms in the open ocean. Progress in Oceanography, 28: 343-383.

Stramski, D., R.A. Reynolds, M. Kahru \& B.G. Mitchell. 1999. Estimation of particulate organic carbon in the ocean from satellite remote sensing. Science, 285: 239242.

Taylor, K.C., G.W. Lamorey, G.A. Doyle, R.B. Alley, P.M. Grootes, P.A. Mayewski, J.W.C. White \& L.K. Barlow. 1993. The "flickering switch" of late Pleistocene climate change. Nature, 361: 432-436.

Thompson, R. 1995. Complex demodulation and the estimation of the changing continentality of Europe's climate. International Journal of Climatology, 15: 175185.

Thompson, R. 1999. A time-series analysis of the changing seasonality of precipitation in the British Isles and neighbouring areas. J. Hydrol., 224: 169-183.

Thompson, R, D. Price, N. Cameron, V. Jones, C. Bigler, P. Rosén, R.I. Hall, J. Catalan, J. García, J. Weckstrom \& A. Korhola (2005) Quantitative calibration of remote mountain lake sediments as climatic recorders of ice-cover duration. Arctic, Antarctic, and Alpine Research, 37: (In press).

Thompson, R., M. Ventura \& L. Camarero. (2005). Hindcasting and downscaling of climate and weather in the European mountains. (Submitted to Freshwater Biology). 
Verbunt, M., J. Gurtz, K. Jasper, H. Lang, P. Warmerdam \& M. Zappa. 2003. The hydrological role of snow and glaciers in alpine river basins and their distributed modelling. J. Hydrol., 282: 36-55.

Wedderburn, E.M. 1908. The freezing of fresh-water lakes. Journal Scottish Meteorological Society, 14: 219-224.

Received: August 2005

Accepted:October 2005
Wielke, L-M., L. Haimberger \& M. Hantel. 2004. Snow cover duration in Switzerland compared to Austria Meteorologische Zeitschrift, 13: 13-17.

Williams, G.P. 1971. Predicting the date of lake ice breakup, Wat. Res. Research, 7: 323-333. 